\title{
Constraining the age of the Côa valley (Portugal) engravings with radiocarbon dating
}

\author{
RONALD I. DORN*
}

\begin{abstract}
Radiocarbon ages for the Côa petroglyphs are very similar to those obtained by Watchman (1995). Fundamental problems in the use of radiocarbon dating at Côa include evidence for the addition of younger carbon in an open system, and evidence of contamination from older sources of carbon. Radiocarbon measurements, therefore, cannot be used to decide whether the engravcings are or are not of Palaeolithic age.
\end{abstract}

The Côa valley petroglyphs (FIGURE 1), galvanizing archaeologists world-wide (Bahn 1995b; Chippindale 1995; Clottes et al. 1995; Jorge 1995; Loendorf 1995; Zilhão 1995c; Züchner 1995), have been a public controversy within Portugal (Salema 1995). Since their existence was made public in November 1994, the uproar created by the possible destruction of this Upper Palaeolithic-style art played an important role in stopping (at least temporarily) a major dam project that would flood the petroglyph sites (Zilhão 1995b).

There are claims that the petroglyphs are definitely not Palaeolithic. Alan Watchman argues that the engravings are younger than 1700 b.p. - based on interpretations of ${ }^{14} \mathrm{C}$ ages associated with rock coatings (Watchman 1995; 1996). Robert Bednarik (1995a; 1995b; 1995c; $1995 \mathrm{~d}$ ) argues for ages younger than 7000 years based on microerosion dating and style. Archaeologically, a recent age for stylistically Palaeolithic art would undermine stylistic analyses of rock art and their chronological basis (Jorge 1995; Zilhão 1995a; Züchner 1995).

My focus is whether available radiocarbon results can constrain the ages of Côa engravings.

\section{Assumption of rock coatings as a closed system}

A key assumption in radiocarbon-dating petroglyphs is that rock coatings form a closed system (Dorn 1994; Watchman 1996). The most common rock coating at Côa is silica glaze, growing on exposed rock surfaces and along subsurface joint faces. Rock coatings of mostly amorphous silica occur in warm deserts (Fisk 1971), in cold deserts (Weed \& Ackert 1986), along tropical rivers (Alexandre \& Lequarre 1978), and in mid-latitude humid temperate settings (Robinson \& Williams 1987; 1992; (Farr \& Adams 1984; Weed \& Norton 1991) that has been used to radiocarbon-date rock paintings (Watchman 1992; 1994) and petroglyphs (Nobbs \& Dorn 1993).

I observed two different types of silica glazes in Côa samples (FIGURE 2). One is mostly silica, likely equivalent to Watchman's $(1995 ; 1996)$ 'white amorphous silica' deposits. The other is silica with abundant aluminium - likely equivalent to Watchman's $(1995 ; 1996)$ 'silty brown' accretion. A minor component of silica glaze, iron skin, occurs in discontinuous patches (FIGURE 2). The texture and geochemistry of silica glaze on petroglyphs is similar to coatings on adjacent natural joint faces and coatings exposed in dam and road cuts.

I agree with Watchman (1995) that aluminiumrich silica glaze is more common, contains detrital grains of various minerals, and typically rests on top of aluminium-poor silica glaze. I also concur that a stratigraphy of 'silica under silty brown' (Watchman 1996: 28) is common on natural joint faces, but this stratigraphic relationship did change from cross-section to

* Geography Department, Arizona State University, Tempe AZ 85287-0104, USA.

Received 17 May 1996, accepted 16 December 1996, revised 10 January 1997.

ANTIQUITY 71 (1997): 105-15 

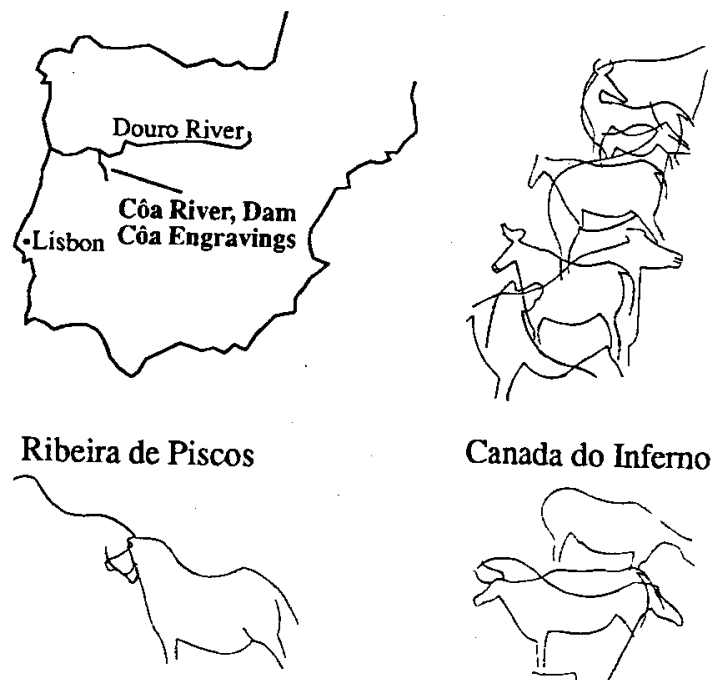

Canada do Inferno

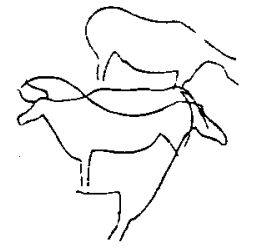

FIGURE 1. Placement of the Côa river valley, a tributary of the Douro River, and the rock art panels that were sampled for dating, modified from Zilhão (1995a).

cross-section. Unlike Watchman (1996: 28), however, I did find some aluminium-poor silica coatings within petroglyph grooves (FIGURE 2). I also observed a variety of complex stratigraphic superpositions of aluminium-poor, aluminiumrich and iron-rich layers.

\section{Radiocarbon methods}

Organic carbon was extracted from five contexts associated with Côa engravings:

i in pore spaces of rock weathering rinds on exposed panel faces;

ii in weathering rinds within petroglyph grooves; iii in weathering rinds collected from unexposed rock crevices;

iv organic matter between rock and coating; and

v a sample from within silica glaze.

Petroglyphs were sampled in a fashion to minimize destruction, while maximizing the possibility for obtaining reliable radiocarbon ages. Sample designations are presented in TABLE 1. Pieces of schist were chipped from each petroglyph with a tungsten-carbide needle. Petroglyphs were sampled at locales where the bottoms of the grooves were $\sim 2-4 \mathrm{~mm}$ beneath the adjacent joint face.

I stress that control samples were collected from the same joint faces as petroglyphs, but in different positions. In the case of FC-95-2b, FC-95-5a, FC-95-8a, control samples were collected close to engravings. Control sample FC95-2a came from within silica glaze where the panel was formerly covered by soil material that had been excavated by archaeologists. In the case of FC-95-5b and FC-95-8b, it was possible to collect samples from $\sim 1-2 \mathrm{~cm}$ within still-unspalled joint faces in places where the overlying block had begun to separate.

For weathering-rind samples, silica glaze was removed with a tungsten-carbide needle under X45 magnification, checked by scanning electron microscopy. For intra-glaze organics and interface organics, silica glaze was mechanically removed with a tungsten-carbide needle under $\mathrm{x} 45$ magnification. The material was pretreated with $\mathrm{HCl}, \mathrm{HF}$ and $\mathrm{NaOH}$ in an approach outlined elsewhere (Dorn 1994).

\section{Radiocarbon in an open system}

Analytical data indicate that silica glaze at Côa does not form a closed system. AMS ${ }^{14} \mathrm{C}$ ages from panel positions range from 4700 b.p. to 18,000 b.p. (TABLE 1); these are much younger than corresponding ${ }^{36} \mathrm{Cl}$ exposure ages (Phillips et al. this issue). The sole exception is panel 14 at Canada do Inferno, where the panel ${ }^{36} \mathrm{Cl}$ age is $16 \cdot 2 \pm 1.5$ ka (table 1 in Phillips et al. 1997, p. 101, above). If silica glaze was closed to the addition of younger carbon, ${ }^{14} \mathrm{C}$ ages for all but one of the panels should be infinite. They are not, and the simplest explanation is continued exchange of organic matter in an open system. Reasonable mechanisms exist for periodic insertion of younger carbon when siliceous coatings spall or dissolve, or epilithic or endolithic organisms add organic matter to the coating (FIGURE 3) or to the weathering rind.

FIGURE 2. Electron microscopy illustrating silica glaze and weathering-rind organics on FC-95-4, a goat engraving at Penascosa. The sample is imaged by backscattered and secondary electrons, and analysed by wavelength dispersive spectrometry. The organic matter, which is black in backscattered electrons and bright in secondary electrons, was verified with wavelength dispersive spectrometry. The upper (aluminium-rich) layer likely corresponds with Watchman's (1995; 1996) 'silty brown' material, and the lower (aluminium-poor) layer likely matches Watchman's 'grey white amorphous silica'. 


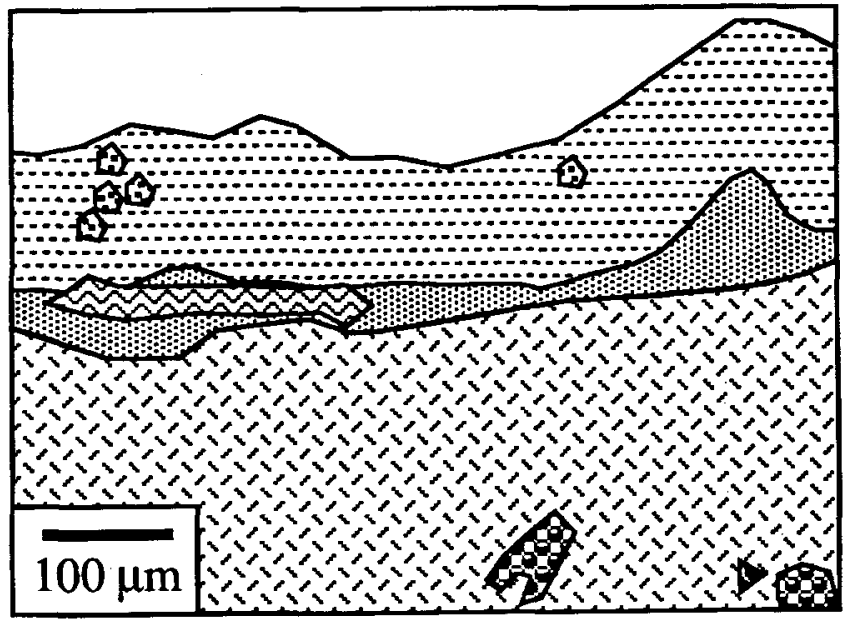

$\because$ silica glaze (Al-rich)

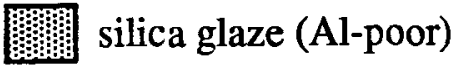

$\approx$ iron skin

organics in silica glaze

89 organic matter in pores

88 of weathering rind

is underlying schist rock

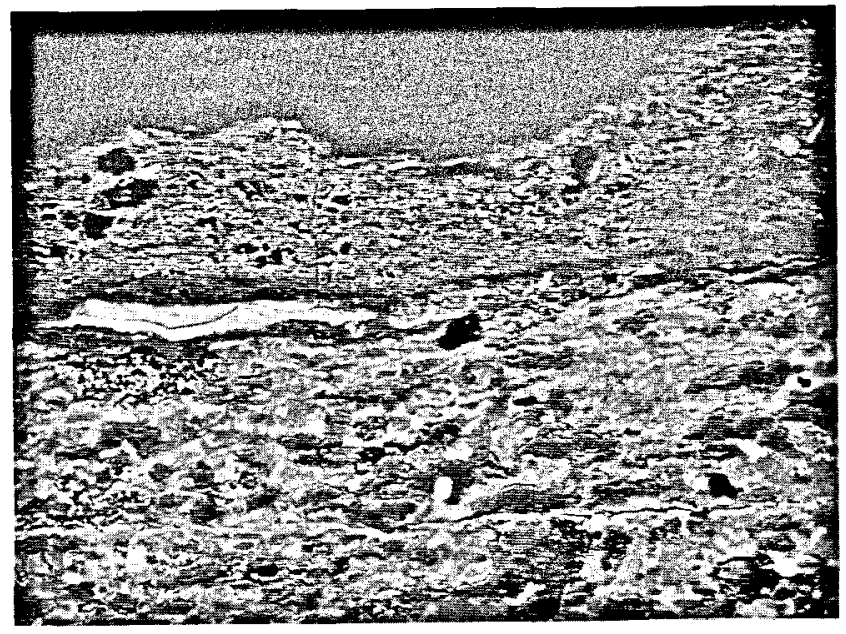

backscatter

image

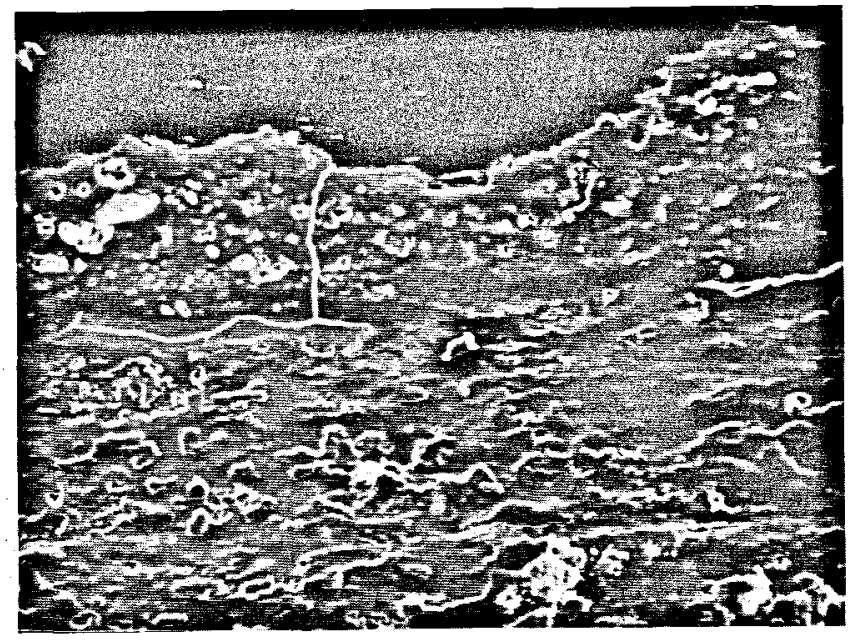

secondary

image 
panel samples

Canada do Inferno

FC-95-2a: Within overlying rock coating

FC-95-2b: Exposed weathering rind

FC-95-2b:Exposed, at the interface between rind and coating

Panel Penascosa

FC-95-5a: Exposed weathering rind

FC-95-5a: Exposed, at the interface between rind and coating

FC-95-5b: Rind within unexposed joint crevice, bulk sample

Sample split of less dense organics

Sample split of dense organics

Ribeira de Piscos

FC-95-8a: Exposed weathering rind

FC-95-8a: Exposed, at the interface between rind and coating

FC-95-8b: Rind within unexposed joint crevice

petroglyph samples

Canada do Inferno

FC-95-1: Left-Oriented Ox

FC-95-3: Upper Horse, 1st sample weathering rind

FC-95-3: Upper Horse, 2nd sample weathering rind

FC-95-3: Upper Horse, interface between rind and coating

Panel Penascosa

FC-95-4: Top Goat, 1st sample weathering rind

FC-95-4: Top Goat, 2nd sample weathering rind

FC-95-6: Big Ox, 1st sample weathering rind

FC-95-6: Big Ox, 2nd sample weathering rind

FC-95-6: Big Ox, interface between rind and coating

Ribeira de Piscos

FC-95-7: Horses, 1st sample weathering rind

FC-95-7: Horses, 2nd sample weathering rind

FC-95-7: Horses, 3rd sample weathering rind

\begin{tabular}{rlr}
\multicolumn{1}{c}{${ }^{14} \mathrm{C}$ age } & lab. no & $\delta^{13} \mathrm{C}$ \\
& & \\
$4700 \pm 70$ & Beta-82450 & $-24 \cdot 9$ \\
$9400 \pm 60$ & Beta-82451 & $-25 \cdot 8$ \\
$18,510 \pm 80$ & Beta-87058 & $-25 \cdot 9$
\end{tabular}

$10,990 \pm 60 \quad$ Beta-82456 $\quad-26 \cdot 8$

$10,300 \pm 60 \quad$ Beta-86013 $-25 \cdot 4$

$23,550 \pm 190 \quad$ Beta-82457 -26.9

$17,460 \pm 70 \quad$ Beta $86632 \quad-26.4$

$29,990 \pm 240 \quad$ Beta $86633 \quad-23.4$

$\begin{array}{rlr}9180 \pm 60 & \text { Beta-82463 } & -25 \cdot 3 \\ 17,090 \pm 70 & \text { Beta-87059 } & -25 \cdot 5 \\ 10,350 \pm 60 & \text { Beta-82464 } & -25 \cdot 6\end{array}$

${ }^{14} \mathrm{C}$ age lab. no $\quad \delta^{13} \mathrm{C}$

$\begin{array}{lll}3700 \pm 60 & \text { Beta-82449 } & -22 \cdot 2 \\ 4350 \pm 60 & \text { Beta-82452 } & -23 \cdot 2 \\ 4590 \pm 50 & \text { Beta-82453 } & -24 \cdot 0 \\ 3980 \pm 60 & \text { Beta-87060 } & -22 \cdot 3\end{array}$

$5010 \pm 50 \quad$ Beta-82454 -24.5

$4960 \pm 60 \quad$ Beta-82455 $-24 \cdot 8$

$2690 \pm 60 \quad$ Beta- $82458 \quad-24 \cdot 6$

$2690 \pm 50 \quad$ Beta-82459 -22.9

$2120 \pm 50 \quad$ Beta-86014 $-22 \cdot 1$

$5480 \pm 60 \quad$ Beta-82460 -23.5

$4540 \pm 60 \quad$ Beta-82461 $-22 \cdot 4$

$5130 \pm 70 \quad$ Beta-82462 $-23 \cdot 1$

TABLE 1. AMS ${ }^{14} \mathrm{C}$ radiocarbon ages on Côa petroglyphs and adjacent natural panel surfaces.

When ${ }^{14} \mathrm{C}$ and ${ }^{36} \mathrm{Cl}$ ages are compared for the same panels, rates of organic carbon exchange appears to be slow. Using open-system radiocarbon theory with bomb carbon (McKay et al. 1986), mixing time constants on Côa panels range from $\sim 15,000$ to 25,000 years. The significance of such slow carbon exchange is exemplified for the Horses engraving at Ribeira de Piscos (TABLE 1). Measured ages of $\sim 5000$ b.p. equate to 'true ages' of $\sim 18,000$ b.p., with mixing constants of $\sim \mathbf{1 0 , 0 0 0}$ years (McKay et al. 1986). In other words, petroglyph grooves could have received a large influx of then-modern carbon in the Palaeolithic when rock faces were exposed to a subaerial environment. Subsequent slow rates of post-engraving carbon exchange would produce observed (TABLE 1) Holocene ages (McKay et al. 1986). Open-system radiocarbon dating is used in soils (Wang \& Amundson 1996), but its potential in petroglyph dating has not heretofore been discussed.

FIGURE 4 presents a hypothetical scenario wherein ${ }^{14} \mathrm{C}$ ages for weathering-rind organics are consistent with both ${ }^{36} \mathrm{Cl}$ ages and a Palaeolithic age for engravings. The 'cartoon' starts with accumulation of organic matter within a joint face in the subsurface. Then, the joint face is exposed $\sim 140,000$ b.p. (e.g. sample FC-958b) - starting the ${ }^{36} \mathrm{Cl}$ clock (Phillips et al. 1997). An open-system of slow-carbon exchange yields finite radiocarbon ages because open exchange 

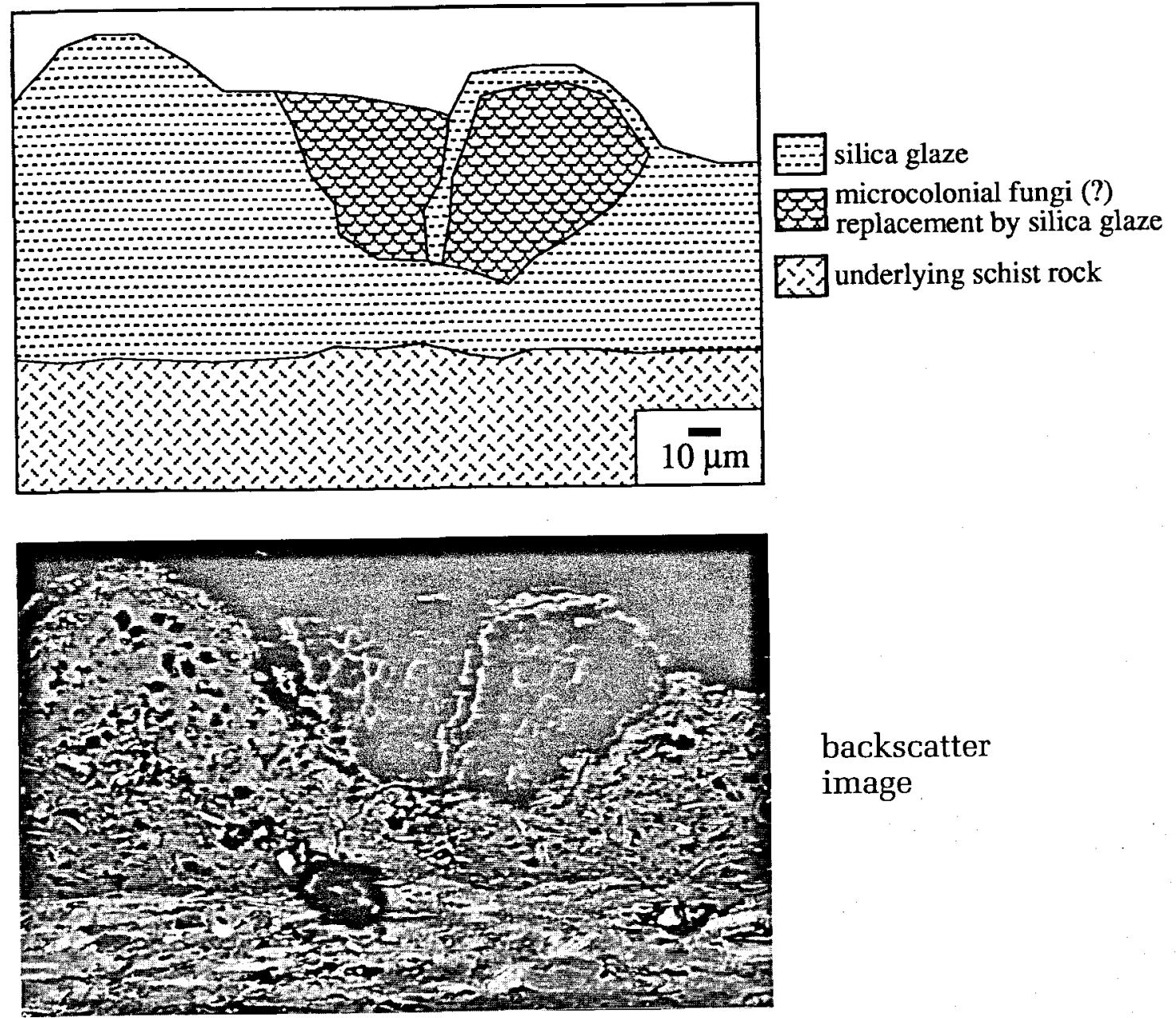

\section{backscatter image}

FIGURE 3. Backscattered electron microscope image of an epilithic organism (microcolonial fungi?) that has eroded silica glaze on FC-95-8a, and in turn is starting to be encapsulated by newly formed silica glaze. This micrograph also shows an unusual circumstance where Al-poor silica glaze (upper part of silica glaze to the left of organism) is on top of the Al-rich silica glaze.

occurs, where the radiocarbon age reflects exchange rates and not the true panel age.

The story of FIGURE 4 changes with an engraving event. In this hypothetical scenario, engraving occurs $\sim 18,000$ b.p. - leading to a large influx of then-modern carbon, as occurs when rock material is exposed to a subaerial environment (Bonani et al. 1988; Chaffee et al. 1994; Farr \& Adams 1984; Krumbein \& Dyer 1985; Nobbs \& Dorn 1993; Weed \& Norton 1991). Petroglyph-manufacturing essentially floods weathering-rinds with 'then-modern' carbon. Carbon exchange slows as silica glaze re-forms. A dynamic equilibrium reinserts itself whereby a slow mixing time constant of carbon ( $c f$. McKay 1986) force ${ }^{14} \mathrm{C}$ ages towards a long-term equilibrium found in 'control' panel weathering rinds. In this hypothetical scenario, weathering-rind organics in panel (control) samples represent a long-term equilibrium condition, and petroglyph ages represent a system disturbed by petroglyph-manufacturing - but one that is moving slowly towards an equilibrium condition. With enough time, petroglyph ${ }^{14} \mathrm{C}$ ages would reach an equilibrium and yield ages similar to adjacent panel faces.

If the model in FIGURE 4 is correct, petroglyph manufacturing could have occurred in the 


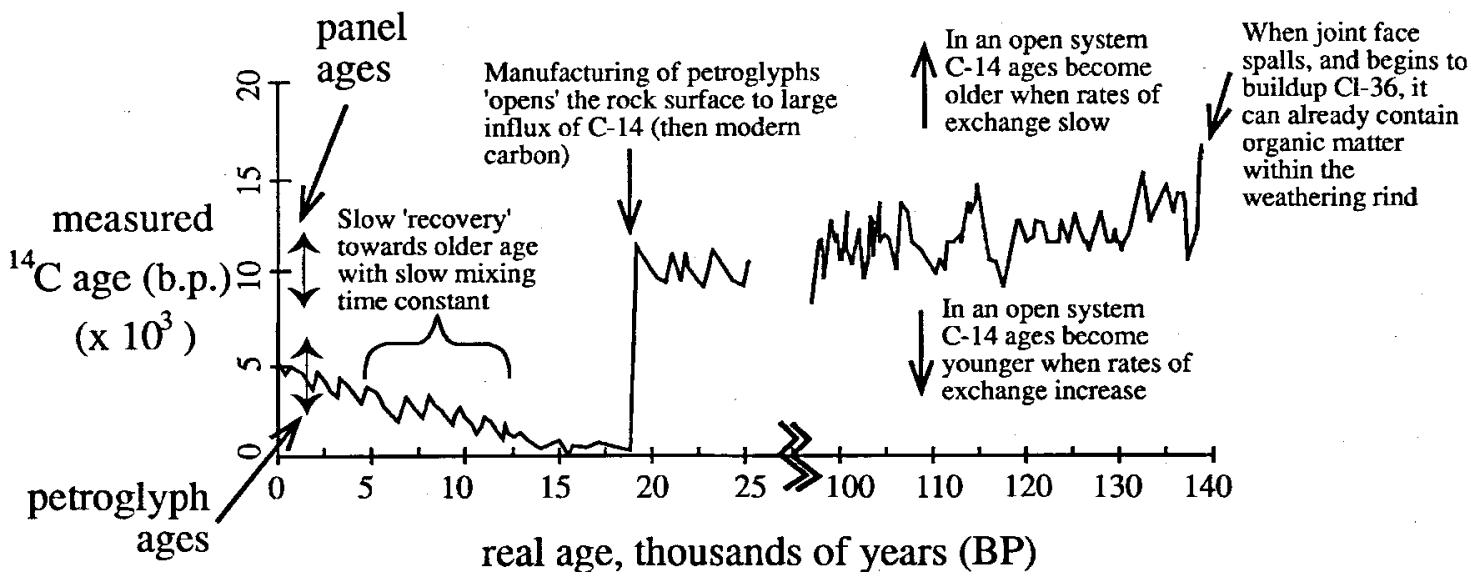

FIGURE 4. In an open system of carbon exchange, this hypothetical scenario illustrates how Côa ${ }^{14}$ C ages (TABLE 1) can be consistent with a Palaeolithic age for the engravings.

Palaeolithic. Using the theory of radiocarbon dating of open systems with the bomb effect (McKay et al. 1986), ${ }^{36} \mathrm{Cl} /{ }^{14} \mathrm{C}$ correlations indicate that mixing times are slow enough for measured petroglyph ${ }^{14} \mathrm{C}$ ages to reflect truly an Upper Palaeolithic genesis. Because exchange rates are uncertain, however, radiocarbon can only provide minimum ages in an open system of carbon exchange (McKay et al. 1986) - that is, if older carbon does not contaminate samples.

\section{Discussion of other problems associated with radiocarbon dating at Côa}

Watchman $(1995 ; 1996)$ used a railroad quarry rock face to show that ancient detrital carbon can become incorporated within silica glazes. I observed the same temporal offset in the sample of intra-glaze organics; sample FC-95-2a yielded an age of $4700 \pm 70$ b.p. (TABLE 1). Watchman (1995) also noted that graphite within the host rock could add ancient organics to weatheringrind samples.

Older petroglyph ages in Watchman's (1995: 108) dataset were explained as being from 'hill slope cultivation' when 'silt began to wash across exposed rock surfaces and into petroglyphs after they were carved.' Watchman's (1995; 1996) hypothesis is that the addition of older organics was the product of human disturbance of the landscape about 1700 years ago.

My data reveals that problems with radiocarbon dating organics on Côa rock faces are more complex and cannot be 'corrected' easily. Consider two stratigraphic inversions in
TABLE1. At panel 14 of Canada do Inferno, weathering-rind carbon ( $9400 \pm 60$ b.p.) is half the age of carbon from an interface position $(18,510 \pm 80$ b.p.). A similar inversion occurs at Ribeira de Piscos, where organics resting on top of the rock $(17,090 \pm 70$ b.p.) are almost twice as old as organics within the underlying weathering rind ( $9180 \pm 60$ b.p.). These inversions either reflect the addition of younger organics into weathering rinds, or more likely reflect ancient organic matter trapped by rock coatings - indicating the insertion of older contaminants long before human cultivation.

There is additional evidence that organic matter can be 'inherited' from a time before subaerial exposure. A ${ }^{14} \mathrm{C}$ age for a still-unexposed joint face at Ribeira de Piscos $(10,350 \pm 60$ b.p.) is older than the exposed face of this joint (9180 \pm 60 b.p.). The offset is even greater at Penascosa, where the exposed sample $(10,990 \pm 60$ b.p. $)$ is much younger than a sample from the unexposed rock crevice $(24,550 \pm 190$ b.p.). Organics from this unexposed Penascosa joint yield different ages for different materials, all within the same sample; porous organics yielded younger ages $(17,460 \pm 70$ b.p.) than dense-shiny organics $(29,990 \pm 240$ b.p.). The existence of older organics in a subsurface position offers another explanation for ancient radiocarbon ages in quarry samples.

Perhaps the best way to understand Côa carbon is to present a general framework of three sources: host rock ; weathering rinds; and on top of weathering rinds. 
Organic matter may be within the host rock. Graphite may occur (Watchman 1995), as may other ancient sources of carbon (Timofeyev et al. 1980). Organic matter can deposit within rocks during weathering episodes all in the subsurface. As discovered in Israel, roots can penetrate in rock joints to depths of over 20 metres - depositing organic matter with radiocarbon ages over 30,000 b.p. (Danin et al. 1987). Micro-organisms are known to weather rocks at great depths (Chapelle \& Bradley 1996; Fredrickson \& Onstott 1996; Fyfe 1996). Ancient roots and microbial remains then undergo diagenesis and can evolve into vitrinite (Chitale 1986) all in the sub-surface.

Organics can also be deposited in weathering rinds before a rock coating forms. Lichens, algae, and fungi can all live within rocks as endolithic organisms (Fyfe 1996; Krumbein \& Dyer 1985; Urzì et al. 1993; Viles 1995). Their remains can comprise ancient organics (Friedmann \& Weed 1987).

Organics can accumulate on top of rocks in three positions. 'Interface' organic matter is deposited in depressions on rock surfaces, all before a rock coating encapsulates organics (Dorn et al. 1992; Soleilhavoup 1992). Organic matter is deposited within layers of rock coatings (Watchman 1995; 1996), or in places where rock coatings have eroded (FIGURE 3). Organics are also found on top of rock coatings.

There is good evidence that the dated organic matter can have a mixed origin. Watchman $(1995 ; 1996)$ argues that the 'brown silty' layer ( $c f$. aluminium-rich layer in FIGURE 2) incorporates ancient organics, and that weathering-rind ages can be contaminated by graphite. My data reveals that ancient organics also occur within rock crevices in the subsurface, and at the interface between the rock coating and underlying rock. Also, different types of organics can be mixed within the same sample. In summary, organics in and under rock coatings can come from the host rock, from erosion of soils, from contemporaneous organics, or from organics deposited long after petroglyphs are engraved.

Consistency with other dating results

In the debate over the antiquity of Côa engravings, there are stylistic arguments in favour of a Palaeolithic age (Bahn 1995a; Clottes et al. 1995; Zilhão 1995a; 1995c; Züchner 1995) and in favour of a Holocene age (Bednarik 1995b; 1995c). I am not qualified to assess these issues.

There is the hypothesis that petroglyphs could have been manufactured at some earlier time, and then re-engraved in the Holocene (Zilhão 1995c). This hypothesis cannot be disproved or supported by my data, by Watchman's $(1995 ; 1996){ }^{14} \mathrm{C}$ data, or by Bednarik's (1995b) microerosion data. The re-engraving event would have introduced younger carbon and would have re-abraded rock surfaces - resetting both ${ }^{14} \mathrm{C}$ and microerosion clocks.

There have been three types of 'direct-dating' data presented in support of a Holocene age: radiocarbon; microerosion dating; and geomorphic instability of the Côa valley. I address each in turn.

\section{Radiocarbon}

${ }^{14} \mathrm{C}$ ages obtained by Watchman (1995) are not in conflict with my ${ }^{14} \mathrm{C}$ data. In fact, there is a similar statistical distribution for the ${ }^{14} \mathrm{C}$ ages (FIGURE 5). While interpretations of these data differ, this blind (Bednarik 1995c: 878) test demonstrates that petroglyph ${ }^{14} \mathrm{C}$ dating is replicable.

I believe that Watchman's $(1995 ; 1996){ }^{14} \mathrm{C}$ ages are consistent with the hypothesis of an open system. ${ }^{14} \mathrm{C}$ ages for intra-silica glaze organics can only be interpreted as minimum ages for the underlying engraving, as long as they are corrected for possible 'older carbon' influences. Organic carbon superimposed on top of an engraving can only have been emplaced after the petroglyph was carved.

In order for petroglyph radiocarbon ages (TABLE 1; Watchman 1995; 1996) to be valid, rock coatings must be closed to the addition of younger carbon. There is only one line of evidence that a closed system may have occurred during the Holocene: weathering-rind organics are older than interface organics for samples from petroglyph grooves (TABLE 1). (This is not true for panel samples.) If siliceous rock coatings in the Côa valley indeed formed a closed system in the Holocene, and weathering-rind organics are not contaminated by older carbon, petroglyphs ages would be between 2100 b.p. and 5500 b.p. (TABLE 1) - in other words between ${ }^{14} \mathrm{C}$ ages for interface organics and ${ }^{14} \mathrm{C}$ ages for weathering-rind organics.

The evidence for a closed system in the Holocene, however, is not overwhelming. Older 


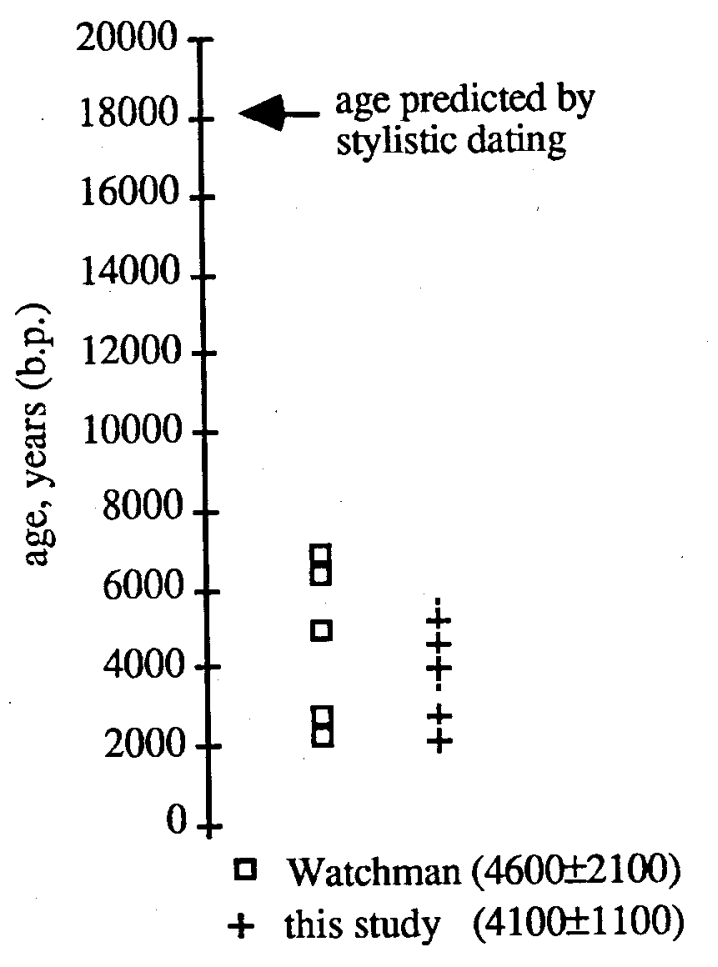

FIGURE 5. A comparison of Côa petroglyph ${ }^{14} \mathrm{C}$ reported by Watchman (1995) and in this study. These radiocarbon ages do not correspond with stylistic dating; the lack of correspondance is likely due to the addition of younger carbon over time in an open system.

weathering-rind ages could simply be from periodic erosion of rock coatings ( $c f$. FIGURE 3 ) - allowing the addition of younger carbon on top of rock surfaces. There is no evidence in Watchman's $(1995 ; 1996)$ data to indicate that silica glaze forms a closed system in the Holocene. More generally, there have been no published tests comparing silica-glaze entombed organics with independent ages. Just because Côa represents the first blind test of petroglyph radiocarbon dating, where ages of two independent and simultaneous investigations occur in the same range (Bednarik 1995c: 878) (FIGURE 5), does not imply that these ${ }^{14} \mathrm{C}$ ages can be use to date Côa petroglyphs.

In summary, I do not believe that it is possible to make an accurate interpretation of Côa radiocarbon ages. Younger carbon is added over time, as demonstrated by comparisons of panel ${ }^{14} \mathrm{C}$ ages and panel ${ }^{36} \mathrm{Cl}$ ages. Older carbon may be added in the form of graphite in weathering rinds (Watchman 1995); detrital organics incorporated into rock coatings (Watchman 1995); detrital organics trapped by rock coatings on rock surfaces (this study); and organic matter from a prior period of rock weathering (this study). There is evidence that different ages of organics can be included in the same sample. There is no independent evidence to believe that petroglyph organics are contemporaneous with petroglyph engraving, either at Côa or in independent tests elsewhere. In summary, petroglyph radiocarbon ages may be too young, too old or just right; they are not easily interpreted.

\section{Microerosion}

I cannot compare my data with ages obtained with the microerosion technique (Bednarik 1995b) for two reasons.

First, silica glaze on engravings prevents microerosion dating from being used (Bednarik 1992: 281):

Since the method uses optical observation, and relies on the assumption that no chemicals have accelerated or retarded the development of erosion phenomena, petroglyphs to be analysed must be free of mineral accretions, or other natural deposits concealing them (including coats of rock varnish, carbonate, oxalate, silica, or lichen).

and (Bednarik 1993: 455-6):

Other preconditions for admissibility are that there must be no mineral deposit covering the petroglyph (which in fact means that the method can only be used where the techniques utilizing accretionary deposits are entirely ineffective).

All engravings samples I observed are covered with silica glaze or epilithic organisms; thus they are inappropriate for dating by the microerosion method. Samples may have been collected where coatings spalled. The lack of silica glaze today, however, would not necessarily mean the rock coating was absent in the past. Furthermore, a lack of silica glaze would indicate that rock faces at Côa are in an open system of carbon exchange.

Second, the microerosion method is complicated by issues of quartz mineralogy, weathering and erosion. There are two general concerns. 


\section{A}

A key assumption of microerosion dating is that quartz surfaces exposed by petroglyph manufacturing are the same type of quartz and are unweathered before engraving. This cannot be assumed, must be tested, and is rarely true ( $c f$. Hochella \& Banfield 1995). There are many different types of crystalline $\mathrm{SiO}_{2}$ that weather differently (Gibson \& LaFemina 1996). At the nanometre-scale of high resolution electron microscopy, quartz weathers to an amorphous state along crystal defects (Pope 1995a). At the micrometre-scale of scanning electron microscopy, quartz weathers internally along largerscale weaknesses (Pope 1995b). When a petroglyph is made, therefore, quartz can be 'pre-weathered' - unless the petroglyph is engraved in newly crystallized magma. This is certainly not the case at Côa - where panels have experienced subaerial weathering for at least 16,000 to 136,000 years, and where joint fractures have been exposed to vadose and phreatic water for untold millions of years. In summary, rates of post-petroglyph quartz microerosion would be highly dependent upon 'inherited weathering' within quartz all assuming the same type of quartz is compared.

Although quartz may look fresh at X45 magnification in the field, it has weathered internally - all before exposure at the surface. At Côa, for example, I noted internal weathering features of holes, fractures and networks in the classification of Pope (1995b); the 'microerosion clock' started long before the petroglyph was made. However, my observations on internal quartz weathering were not quantitative; replicate measurements on inherited quartz weathering should be made on the same grains that are analysed for microerosion ( $c f$. Pope 1995a; 1995b).

\section{B}

Although a variety of surface weathering textures do permit qualitative distinctions between different weathering environments (e.g. Mahaney 1996), 'after 60 years of research, the complexity of [quartz] grain shapes and surface textures produced by weathering processes continues to limit quantitative correlation of textures and histories of soils and sediments' (Dove 1995: 240).
Geomorphic instability

Bednarik (1995c; 1995d) and Watchman (1996) used deductive arguments to suggest that the landscapes and rock surfaces of Côa are too unstable to support Palaeolithic art. In contrast, ${ }^{36} \mathrm{Cl}$ ages for petroglyph panels, ${ }^{36} \mathrm{Cl}$ ages for associated joint faces and ${ }^{36} \mathrm{Cl}$ ages for hillslope materials (table 1 in Phillips et al. 1997, above) all argue for a landscape that is stable enough to support Palaeolithic art.

\section{Conclusions}

Although available data are not definitive, there are several reasons why I favour a Palaeolithic age for Côa art.

First, although Côa provided the context for the first blind test of petroglyph radiocarbon dating (FIGURE 5), and although the "primary radiocarbon dates of Watchman and Dorn represented the same range' (Bednarik 1995c: 880) of Holocene ages, I do not believe that these radiocarbon ages provide definitive results. There is good evidence that Côa rock coatings do not form a closed system. There is evidence that ages can mix different types of organics, and that contamination from older and younger material is likely.

Second, ${ }^{36} \mathrm{Cl}$ ages reveal that all of the sampled panels were exposed and available for engraving during the Upper Palaeolithic. Furthermore, ${ }^{36} \mathrm{Cl}$ ages reveal that rates of rocksurface erosion are slow enough to preserve Palaeolithic art (Phillips et al. 1997). Unlike the radiocarbon tests in railroad cuts (Watchman 1995) and unexposed joint faces (this study), where evidence of contamination was revealed, the dam excavation test revealed virtually no potential for 'inherited' ${ }^{36} \mathrm{Cl}$ (Phillips et al. 1997).

Third, if petroglyph radiocarbon ages are indeed accurate and not contaminated by younger or older carbon, measured ages could truly reflect manufacturing during the Upper Palaeolithic. Using ${ }^{36} \mathrm{Cl}$ panel ages (Phillips et al. 1997), ${ }^{14} \mathrm{C}$ ages for panel weathering-rinds (TABLE 1) and open-system radiocarbon theory (McKay et al. 1986), mixing time constants would be sufficiently slow for measured petroglyph ages to fall within the Upper Palaeolithic.

Fourth, I think it unlikely that all of the sampled petroglyphs were re-engraved. But if they were, it would still mean that the engravings 
pre-dated the measured petroglyph ${ }^{14} \mathrm{C}$ ages and could be Palaeolithic.

In summary, the only unambiguous data on the age of Côa art come from ${ }^{36} \mathrm{Cl}$ ages - indicating that panels were available for engraving during the Palaeolithic (Phillips et al. 1997). Because ${ }^{14} \mathrm{C}$ ages may be contaminated by older

\section{References}

ALEXANDRE, J. \& A. LEQUARRE. 1978. Essai de datation des formes d'erosion dans les chutes et les rapides du Shaba, GeoEco-Trop 2: 279-86.

BAHN, P.G. 1995a. Cave art without the caves, Antiquity 69: 231-7.

1995b. Outdoor creations of the Ice Age, Archaeology 48(4): 37.

BEDNARIK, R.G. 1992. A new method to date petroglyphs, Archaeometry 34: 279-91.

1993. Geoarchaeological dating of petroglyphs at Lake Onega, Russia, Geoarchaeology 8: 443-63.

1995a. Coa Valley Portugal: dating the Coa petroglyphs, Victorian Anthropological and Archaeological Society Bul letin 1995(4): 5-8.

1995b. The age of the Côa valley petroglyphs in Portugal, Rock Art Research 12(2): 86-103.

1995c. The Côa petroglyphs: an obituary to the stylistic dating of Palaeolithic rock-art, Antiquity 69: 877-83.

1995d. More news from Hell's Canyon, Portugal, AURA Newsletter 12(1): 7-8.

BONANI, G., E.I. FRIEDMANN, R. OCAMPO-FRIEDMANN, C.P. MCKAY \& W. WOELFLI. 1988. Preliminary report on radiocarbon dating of cryptoendolithic microorganisms, Polarforschung 58: $199-200$.

CHAFFEE, S.D., L.L. LOENDORF, M. HYMAN \& M.W. Rowe. 1994 A dated pictograph in the Pryor Mountains, Montana Plains Anthropologist 39: 195-201.

ChaPELle, F.H. \& P.M. BRADLEY. 1996. Microbial acetogenesis as a source of organic acids in ancient Atlantic Coastal Plain sediments, Geology 24: 925-8.

ChIPPINDALE, C. 1995. Editorial, Antiquity 69: 863-70.

CHITALE, J.D. 1986. Study of petrography and internal structures in calcretes of West Texas and New Mexico (Microtextures, Caliche). Lubbock (TX): Geosciences Department, Texas Tech University.

ClotTES, J., M. LORBLANCHET \& A. BELTRÁN. 1995. Are the Foz Cốa engravings actually Holocene?, International Newsletter on Rock Art 12: 19-21.

DANIN, A., M. WIEDER \& M. MAGARITz. 1987. Rhizofossils and root grooves in the Judean Desert and their paleoenvironmental significance, Israel Journal of Earth Sciences 36 91-9.

DORN, R.I. 1994. Dating petroglyphs with a 3-tier rock varnish approach, in D.S. Whitley \& L. Loendorf (ed.), New light on old art: advances in hunterer-gatherer rock art research: 12-36. Los Angeles (CA): UCLA Institute for Archaeology. Monograph Series 36.

DORN, R.I., P.B. ClARKSON, M.F. NOBBS, L.L. LOENDORF \& D.S. WHITLEY. 1992. New approach to the radiocarbon dating of rock varnish, with examples from drylands, Annals of the Association of American Geographers 82: 136-51.

Dove, P.M. 1995. Kinetic and thermodynamic controls on silica reactivity in weathering environments, in A.F. White \& S.L. Brantley (ed.). Chemical weathering rates of silicate minerals,: 235-90. Washington (DC): Mineralogical Society of America.

FARR, T. \& J.B. ADAMS. 1984. Rock coatings in Hawaii, Geological Society of America Bulletin 95: 1077-83.

Fisk, E.P. 1971. Desert glaze, Journal Sedimentary Petrology 41: $1136-7$. materials, younger materials, or both, it difficult to make definitive conclusions based on ${ }^{14} \mathrm{C}$ evidence.

Acknowledgements. I thank Antonio Vidigal and Electricidade de Portugal for funding this research, ASU for sabbatical support and J. Clark for assistance in electron microscopy.

FREDRICKSON, J.K. \& T.C. ONSTOTT. Microbes deep inside the earth, Scientific American 275 (4): 68-73.

FRIEDMANN, E.I. \& R. WEED. 1987. Microbial trace-fossil formation, biogenous, and abiotic weathering in the Antarctic cold desert, Science 236: 703-5.

FyFE, W. S. 1996. The biosphere is going deep, Nature 273: 448.

GiBSON, A.S. \& J.P. LAFEMINA. 1996. Structure of mineral surfaces, in P.V. Brady (ed.), Physics and chemistry of mineral surfaces,: 1-62. Boca Raton (FL): CRC Press.

HOCHELLA, M.F., JR \& BANFIELD, J.F. 1995. Chemical weathering of silicates in nature: a microscopic perspective with theoretical considerations, in A.F. White \& S.L. Brantley (ed.), Chemical weathering rates of silicate minerals,: $353-$ 406. Washington (DC): Mineralogical Society of America.

JoRGE, V. O. (ed.) 1995. Dossier Côa. Porto: Sociedade Portuguesa de Antropologia e Etnologia.

KRUMBeIN, W. E. \& B. D. DYER. 1985. This planet is alive weathering and biology, a multi-faceted problem, in J.I. Drever (ed.), The chemistry of weathering: 143-60. Dordrecht: D. Reidel.

LOENDORF, L. 1995. Ice age engravings in danger, La Pintura 21(3): 12-13

MAHANEY, W.C. 1996. Scanning electron microscopy of quartz sand from the north-central Saharan desert of Algeria, Zeitschrift für Geomorphologie Supplement Band 103: 179-92.

McKaY, C. P., A. LONG \& E. I. FRIEDMANN, 1986. Radiocarbon dating of open systems with bomb effects, Journal Geophysical Research 91(B3): 3836-40.

NoBBS, M. \& R. I. DORN. 1993. New surface exposure ages for petroglyphs from the Olary Province, South Australia, Archaeology in Oceania 28: 18-39.

Phillips, F. M., M. Flinsch, D. Elmore \& P. Sharma. 1997. Maximum ages of the Côa valley (Portugal) engravings measured with ${ }^{36} \mathrm{Cl}$, Antiquity 71: 100-104.

POPE, G.A. 1995a. Newly discovered submicron-scale weathering in quartz: geographical implications, Professional Geographer 47: 375-87.

1995b. Internal weathering in quartz grains, Physical Geography 16: 315-38.

ROBINSON, D.A. \& R.B.G. WILLIAMS. 1987. Surface crusting of sandstones in southern England and northern France, in V. Gardiner (ed.), International geomorhpology 1986 Part II: 623-35. London: Wiley.

1992. Sandstone weathering in the High Atlas, Morocco, Zeitschrift für Geomorphologie 36: 413-29.

SAlEMA, I. 1995. Alan Watchman ao PUBLICO: um paleolítica 'absurdo', Público 8 July (Lisbon): 25.

Soleilhavour, F. 1992. Scientifiques et touristes dans les sites d'art rupestre de plein air: des règles à appliquer; une déontologie à fixer, Bolletino del Centro Studi e Museo d'Arte Preistorica di Pinerolo, Italia 7-8: 81-97.

TIMOFEYEV, G.I., I.D. MINEYEVA \& V.P. GRUSHEVSKIY. 1980. Use of EPR for analyzing insoluable organic matter of rocks, International Geology Review 22 (3): 369-72.

Urzì, C., G. Criseo, W.E. KRUMBEIN, U. WOLLENZIEN \& A.A. GORBUSHINA. 1993. Are colour changes of rocks caused by climate, pollution, biological growth, or by interactions of the three?, in M.-J. Thiel (ed.), Conservation of stone and other materials: 279-86. London: E. \& F.N. Spon. 
VILES, H. 1995. Ecological perspectives on rock surface weathering: towards a conceptual model, Geomorphology 13: 21-35.

WANG, Y. \& R. AMUNDSON. 1996. Radiocarbon dating of soil organic matter, Quaternary Research 45: 282-8.

Watchman, A. 1992. Potential methods for dating rock paintings, American Indian Rock Art 18: 43-51.

1994. Evidence of paleoenvironments in rock surface accretions, Program Abstracts, 1994 International Rock Art Congress, Flagstaff : 33-4.

1995. Recent petroglyphs, Foz Côa, Portugal, Rock Art Research 12(2): 104-8.

1996. A review of the theory and assumptions in the AMS dating of the Foz Côa petroglyphs, Portugal, Rock Art Research 13(1): 21-30.

WEED, R. \& R.J. ACKERT. 1986. Chemical weathering of Beacon Supergroup sandstones and implications for Antarctic glacial chronology, South Africa Journal of Science 82: 513-16.
WEED, R \& S A. NORTON. 1991. Siliceous crusts, quartz rinds and biotic weathering of sandstones in the cold desert of Antarctica, in J. Berthelin (ed.), Diversity of environmental biogeochemistry: 327-39. Amsterdam: Elsevier. Developments in Geochemistry 6.

ZıLHÃo, J. 1995a. The age of the Côa valley (Portugal) rock-art: validation of archaeological dating to the Palaeolithic and refutation of 'scientific' dating to historic or proto-historic times, Antiquity 69: 883-901.

1995b. Foz Côa dam canceled. New Archaeological Park Planned, La Pintura 22 (2): 1-2.

1995c. The stylistically Paleolithic petroglyphs of the Côa Valley (Portugal) are of Paleolithic age: a refutation of their 'direct dating' to recent times, Trabalhos de Antropologia e Etnologia 35(4): 119-65.

ZÜCHNER, C. 1995. Some comments on the rock art of Faz Côa (Portugal), International Newsletter on Rock Art 12: 1819. 